\title{
Promoting non-timber forest products (NTFPs) to alleviate poverty and hunger in rural South Africa: $A$ reflection on management and policy challenges
}

\author{
D. D. Tewari \\ School of Accounting, Economics and Finance, University of KwaZulu-Natal (UKZN), Province of KwaZulu-Nata, Durban \\ South Africa. E-mail: Tewari@ukzn.ac.za or davetewari@gmail.com.
}

Accepted 3 October, 2012

\begin{abstract}
South African forests provide a variety of non-timber forest products (NTFPs) ranging from building materials to food and medicinal products. Economically speaking, the NTFPs sustain the rural and periurban poor in meeting their subsistence needs; about $85 \%$ of households in rural South Africa use NTFPs in their daily lives. The shortage of NTFPs is bound to intensify the impacts on rural poor. It is to be noted that continual under-reporting of NTFPs from forests and woodlands has resulted into lesser importance being attached to them in the national accounting; consequently their role in supporting livelihoods and food security is also undermined at the policy formation stage. NTFPs can play a bigger role in South Africa by mitigating the effects of hunger and malnutrition and engendering rural development. The study highlights challenges that South Africa faces to develop the NTFP sector to leverage the rural development objective and suggests a policy framework which can attain it
\end{abstract}

Key words: Non-timber forest products (NTFPs), South Africa, millennium development goal, policy, medicinal, forests.

\section{INTRODUCTION}

In South Africa, about 35\% people live below the poverty line of US\$2 per day or R174 per month in 2005 prices (United Nations Development Programme (UNDP), 2005: 11). In terms of urban-rural breakdown, about $19 \%$ of the South African population lives in rural areas (Central Intelligence Agency (CIA), 2009). The access to modern medical aid is primarily limited to urban sector dwellers who are employed. Given the very high unemployment rate of $24 \%(C I A, 2009)$, it is understandable that a large population has to subsist upon alternative food and health materials.

The NTFPs are a rich resource to the underprivileged population in terms of livelihood, food and health security ${ }^{1}$. For example, about $85 \%$ of households in rural

\footnotetext{
${ }^{1}$ As per the expert consultation of Food and Agriculture Organization (FAO), the non-wood forest products (NWFPs) consists of goods of biological origin other than wood, as well as services, derived from forests and allied uses (FAO, 1999) This definition thus excludes all woody materials such as charcoal and fuel wood, small woods such as tools, household equipments and carvings. The
}

South Africa use NTFPs in their daily lives and most commonly used products are wild spinaches, fuelwood, wooden utensils, edible fruits, grasses, fodder, bush meat, and others (Shackleton and Shacklelton, 2004; FAO, 1994). Based on a survey of villages in Limpopo, it was estimated that on an average a household extracts about 5.3 tonnes of fuelwood, $58 \mathrm{~kg}$ of wild spinaches, $104 \mathrm{~kg}$ of edible fruits and 185 large poles for fencing kraals and houses (Shackleton and Shackleleton, 2004: 658).

NWFP can originate from natural forests or plantations. Both forests services (ecotourism, grazing and bioprospecting) and forest benefits (soil conversation, soil fertility, and watershed probation) are excluded. This means only tangible and physical products of biological origins such as plants, animals and related products are counted. In brief, NWFPs include all tangible outputs from forests or from other wooded land which exclude timber, forest services and forest benefits. The non timber forest products (NTFPs) consists of all NWFPs plus fuel wood and small woods (FAO, 1999). In this article the focus is on the NTFPs in South Africa. 
Based on a 2 year study in two villages of South Africa, Paumgarten and Shackleton (2011) found that $70 \%$ of households used NTFPs as a safety net in times of food shortages. In south-eastern Zimbabwe, it was found that extraction of NTFPs was a coping mechanism to occurrence of HIV-AID to smooth consumption. About $48 \%$ of household's income shortfall due to the disease was offset by extraction of NTFPs (Mutenje et al., 2011). Furthermore, most NTFPs are collected from the nature and thus result in cost savings which enable households to use cash for other worthy investments such as education of children. These cost savings are translated into billions of rands if government were to provide these benefits to rural poor. Besides providing food security, NTFPs also generate income and employment for many rural people. The increasing commercialization is making NTFPs economically attractive. The markets for NTFPs are developing rapidly in the country; for example, local sellers of marula beer in Bushbuckridge in Limpopo province increased from 15 to 150 between 1998 and 2002; and, in Kat River area of Eastern Cape some 30\% of households sold NTFPs (Shackleton and Shackleton, 2004: 660).

In addition to daily use of NTFPs, many of them are used as medicines. For example, about $80 \%$ of all people in South Africa use medicinal plants for healthcare as the cost of consulting western style doctors and price of medication are beyond the means of most people (WHO, 2002; Dyson, 1998). A large population of South Africa, including those who are privileged and have access to modern medicines, depends upon the traditional medicines for primary healthcare needs. For example, a study in Durban in KwaZulu-Natal indicated that black people used some $60 \%$ of healthcare services from western health care system and $40 \%$ of the services demanded came from indigenous medicines (Mander, 1998). For instance, households in KwaZulu-Natal spent some 4 to $8 \%$ of their annual income on indigenous medicines (Mander, 1998).

NTFPs are also source of income for rural poor. The World Bank study in 2004, based on case studies from 17 countries from three continents, focusing especially on Africa, found that some $22 \%$ of income of rural poor originated from forests; and, it can be as high as $40 \%$ of total income at times (Vedeld et al., 2004). Estimated cash flows from NTFPs ranged from US $\$ 194$ to US $\$ 1114$ per year over a series of seven studies in South Africa (Shackleton et al., 2000).

In brief, the NTFPs constitute an important resource to provide livelihood and food security through their large income employment generation potential and health security by way of supplying indigenous herbs and medicines to indigent rural citizens of the country. NTFPs can thus be used to mitigating the miseries of rural poor people, thus contributing to alleviation of poverty and hunger. As per the Millennium Development Goal One
(MDG1), South Africa as a nation is committed to halve the population of people whose income is less than one dollar (PPP values) per day between 1990 and 2015. A NTFP-promoting strategy can enhance the rate of achievement of target and be used to supplement theover-all government strategy toward meeting this goal. However, we need to be careful in exploiting this resource so that it is managed on a sustainable basis.

In many parts of the world, evidences now exist that over-extraction of NTFPs can destroy or extinct this resource (Padoch, 1988; Kusters et al., 2006). A policy framework for sustainable management of NTFPs is the need of the hour. Interestingly enough, the development of NTFPs can produce sustainable income support to people. A comprehensive understanding of issues related to the NTFPs will provide insights to policymakers and help develop policies to promote and effectively use this resource to alleviate poverty and hunger and achieve the MDG1 in South Africa and engender rural development.

The major objective of the study is to highlight the role of NTFPs in the subsistence sector of the economy as a resource for alleviation of poverty and hunger and outline the developmental role that it can play in the lives of under privileged and indigent citizens of the country. More specific objectives are:

1. To highlight the most important NTFPs in South Africa; 2. To give an account of the collection and marketing activities of NTFPs in South Africa;

3. To discuss the income and employment generation potential of the NTFPs for the poor; and

4. To reflect on management and policy challenges for efficient management of this natural resource for alleviation of poverty and hunger and use of NTFPs as policy instrument to create rural development.

The discussion of this study is shown subsequently. After this study was introduced, a review was done on the economic significance of the NTFPs by way of discussing some of the most important NTFPs in South Africa. This is followed by providing a brief discussion on how NTFPs are collected and marketed in the country, after which their income and employment generation potential is discussed. Major management and policy challenges that lay ahead to invigorate the NTFPs for enabling it to play the desired developmental role in the economy are then discussed. The summary and conclusions are discussed at the end.

\section{SOME MOST IMPORTANT NTFPS OF SOUTH AFRICA}

The NTFPs abound in South Africa and most people use them daily basis. The consumers or users of NTFPs are spread across rural and peri-urban areas and in cities too. The rural and peri-urban people in South Africa use a 
variety of NTFPs listed subsequently (Shackleton and Shackleton, 2004): fuelwood; building and household materials; handicrafts; gathered foods; grasses and fodder; medicinal plants; other vegetal NTFPs; faunal NTFPs. This list is not exhaustive but covers most NTFPs in the country. A brief discussion on each follows.

\section{Fuelwood}

Fuelwood is a major NTFP in South Africa. Most rural and peri-urban households (between 80 and $90 \%$ of total) even today continue to use fuelwood as the primary source of energy despite the heavy government intervention to supply electricity to the households since 1994 (Griffin et al., 1992; Williams and Shackleton, 2002). This is because the majority of population cannot afford the electric appliances and the monthly costs/payments for the electricity (White et al., 1997). Fuelwood is also a source of income to many poor people; for example, some 7 to $53 \%$ of people in Bushbuckridge area of Limpopo province traded in fuelwood (Shackleton et al., 2000).

The bulk of South Africa's poor live in the wooded biomes, especially woodlands, in Limpopo, KwaZuluNatal, and the Eastern Cape (Damm and Triebel, 2008). More than $80 \%$ of the households use fuelwood as their primary source of energy (Damm and Triebel, 2008). Some 2.3 to $2.8 \%$ out of about 12 million households (about 12 to 15 million out of 49 million people), that is about 25 to $30 \%$ of total population of South Africa, depend entirely on fuelwood for energy needs (Damm and Triebel, 2008). The total fuelwood consumption is estimated to be about 11.2 million tons-representing approximately $40 \%$ of total energy consumption in the residential sector (Damm and Triebel, 2008) ${ }^{2},{ }^{3}$ The total direct use value of fuelwood to households is estimated at R4.5 to 5.5 billion (US\$ 0.64 to $0.78 \mathrm{~b}$ using $\mathrm{R} 7=$ 1US\$) per annum (Damm and Triebel, 2008).

The fuelwood supply originates from many sources and their contribution to total supply varies as follows: natural woodland $(60 \%)$, commercial plantation $(9 \%)$, indigenous forest $(2 \%)$, woodlots $(4 \%)$, trees outside forests $(13 \%)$, other sources (12\%) (Damm and Triebel, 2008). A brief description of sources of fuelwood supply is given in Table 1. The overall demand for fuelwood is not expected to decline in coming years due to low rate of substitution by electricity (Williams and Shackleton, 2002).

\footnotetext{
${ }^{2}$ The three major sources of energy in the residential sector are coal (25\%), electricity (27\%), and fuel wood (39\%). The three biggest energy-using sectors are industry (36\%), transport (26\%), and residential use (18\%), consisting more than $70 \%$ of total energy consumption in the country (DME, 2006).

${ }^{3}$ Some other estimates suggest that about 12 to 13 million cubic metres of fuel wood are used annually in South Africa (Department of Minerals and Energy (DME), 1966); Williams and Shackleton, 2002).
}

\section{Building and household materials}

In rural areas of South Africa, people rely on NTFPs as a source of construction of traditional grass thatched houses. The temporary structures such as sheds, barns, pens for livestock and permanent structures such as mud houses (which are built of mud hut with wooden structural frames or built entirely of wood, bricks or cement blocks with wooden parts) dominate the rural and peri-urban shelter construction. Species used to provide skeletal frames for structures include climbers: Landolphia Kirkii, Hippocralea delagoensis, Abrus precatoriou, Monanthotaxis caffra, Uvaria caffra, Uvaria lucida, Flagellavia guineensis, leaves of Sansevieria guineesis, Sansevieria hyachinthoies, leaf petioles of Strelizia nicolai and tree bark of Ficus trichpoda (Cunningham et al., 1988).

The wood use for building varies with building style and availability of materials. Cunningham et al. (1988) estimated wood consumption to be 0.23 tonnes/ family/ year or at least to lay between 0.16 to 0.18 tonnes/ family/year in Temba-Tonga hut construction due to the popularity of Phtagmites reeds rather than laths for wall construction. The building style such as 'beehive' traditional Ngwane and Zulu hut uses up to 1000 laths per hut (Cunningham et al., 1988).

In the Eastern Cape, the following species are popular for traditional house construction: Buxus macowatiii, Buxus nalaleuis, Cryptocarya woodii, Pavetta laticeolata, Duvernoia adhatodoides, Plaeroxylon obliguum, Apodyles dimidiate, Drypes arguta, Tricalysia, motiodorajiitiodii and Hymenocardia umoides (Cunningham et al., 1988).

A number of NTFPs are used in South Africa in the form of equipments, materials, and other goods. These items include sticks, sweeping brooms, pestles, mortals, stools, bowls, plates cutlery and domestic utensils. Also mats (obtained from iNduma materials), which are used as either bedding materials or as screens, blinds, wall hangings and materials on which food items are dried, are made from the fibres of plants obtained from swampy areas or papyrus. Sweeping brooms are made from the midribs of the leaflets of palm trees such as ilala and grass known as Ngogoni in local Zulu. In South Africa, demand for sweeping broom is not actually confined to the poor only. The broom is used for sweeping even carpeted floors. It is also very popular for outside yards and verandah. The materials used are obtained from the forests and the handle or the straight stick is approximately $1.5 \mathrm{~m}$ long obtained from tree called iNdukho in local Zulu.

The wood of Colohospermum mopane, Diospyros mespiliformis, Conbretum apiculatum, Acacia nigrescens, Sclerocarya birrea, Terminatia serice, Cambretum imberbe is used for making household utensil such as mortars, pestles, spoons, plates, walking sticks, 
Table 1. Sources of fuel wood supply, South Africa.

\begin{tabular}{llcc}
\hline Sources & Area & Population & Annual supply \\
\hline Natural woodlands & $42 \mathrm{~m}$ ha everywhere in South Africa & 9.2 million & $6-7$ million ton /annum \\
Commercial population & $1.35 \mathrm{~m}$ ha in Mpumalanga, KwaZulu-Natal and Eastern Cape & --- & 1 million ton/annum \\
Indigenous forests & 350 thousand hectares & --- & Not known \\
Woodlot & 50 thousand hectares & --- & 0.5 million ton/annum \\
Trees outside forests & ---- & --- & --- \\
& & & 0.5 million ton/annum \\
Processed waste & Off cuts from 200 sawmills and other downstream timber & \\
& product manufacturers & --- & 12 million ton/annum \\
Alien species & --- & --- & - \\
Others & --- & &
\end{tabular}

Constructed from Damm and Triebel (2008).

decorations and hand hoes for ploughing in Limpopo (Makhado et al., 2009). These utensils use high volume of wood; for example, about 0.091 cubic metres for a mortar and 0.003 cubic metres for a pestle. Traditionally, mortar and pestle are used for pounding maize, peanuts and in preparation of medicines (Makhado et al., 2009). There is also a variety of agricultural equipments and tools which are very much in demand. These equipments may include items such as gun-stocks, harvesting cats pulled by oxen, hoe handles, wooden ploughs, spear shafts, baskets, calabashes and bowls obtained from indigenous tree materials.

\section{Handicrafts}

NTFPs are also used as handicrafts in the form of hardwoods for sticks, grinding mortars and domestic items such as meat dishes. A number of home crafts are practised in many regions and it forms an important part of the local economy. Since 1970s, there has been a dramatic increase in the production and sale of handicrafts by rural entrepreneurs and non-profit organizations (Preston-Whyte, 1983; Cunningham, 1987). Handicraft industry requires low capital outlay and traditional skills and uses locally available resources; the fact which has made it grow rapidly. A case in point is the Port St. Jones in the eastern former Transkei (now in Eastern Cape province) among Pondo people. In this region home crafts such as baskets and mats are the most economically important items. These crafts utilise particular raw material obtained from the indigenous forest. For example, each basket is made up of several different raw materials using Onicinotis inandensis for basic framework, M. caffra for the ribs, and Flagelleria quineenis for weaving. The indigenous plant species are the major raw material for this industry. The industry grew very well in 1980s and had a value of R100, 000 per annum (Cunningham et al., 1988: 7). It has grown since then by leaps and bounds.

Many other items are commercially sold as handicrafts. For example, the wooden meat dishes of Balanites maughatnii and Spirostachys Africana come from sand forests; sticks, which are on demand by tourists in urban areas, come mainly from Cleislanthus schlechteri, Ochna arbonea, Ochna natalitia, Drypetes gerrardii, and Saychnos henningsii from Nkandla forest; Oncinoti inandensis stems for basket frames and handles originate from Port St. Johns area. The palms Hyphaene coriacea and Phoenix reclinata are very much used by rural people in Maputaland coastal plain of Kwazulu-Natal as they are source of weaving material, palm wine and edible fruits (FAO, 1994).

\section{Gathered foods}

A number of NTFPs are collected for food by people; these include edible fruits, wild spinaches, honey, honeybees, edible mushrooms, termites, stink bugs, mopane worms, edible locusts, and so on. These foods supplement the diets of people and are also used for satisfying of hunger during draught period in marginal agricultural areas (Grivetti, 1979). Wild spinaches grow in KwaZulu-Natal and surrounding areas at a very high density in Dune forest (Cunningham et al., 1988: 5). They also grow in sand forest and fallow fields.

Mopane worms provide a good nutritional source as they are rich in protein and fats. They also create seasonal employment opportunities. Makhado et al. (2009) noted that in their study area (Northeast Limpopo) about $71 \%$ villages collected mopane worms for subsistence and $29 \%$ sold them for income generation. Stink bugs are also used for supplementing the food (Teffo, 2006). Stink bugs are also sold for incomes. Termites are eaten in most parts of Southern Africa 
(Bower, 2001) and are good source of protein (Chanyenga, 1998 to 2000; Bower, 2001). Edible locusts are also consumed in most rural areas of north eastern South Africa and contain high quantities of protein and fats (Crafford, 1991; Adler, 1934). Wild mushrooms are also other rich source of protein (27 to $48 \%$ protein). Honey and honeybees are also collected. Honeybee larvae are harvested for food (Junod, 1913).

\section{Fibres and fodders}

Many trees produce fibres which are used in the cottage industry. For example, the bark fibres of baobab tree are used for cordage, basketry, mats and cloths; its root bark is used for making string for nets, socks, and mats (Booth and Wickens, 1988). The fibres of bastard brandy bush (Grewia bicolor) are used for making string, rope and cordage. Other fibre producing trees are radish tree (Moringa Oleifera) and violet tree (Securidaca longepedunculata). Besides trees, grasses like Abrus precatorius and Flagellaria guineensis are commonly used climbers (FAO, 1994).

A number of tree and shrub species supply various fruits, seeds, nuts and roots for human consumption and forages for livestock consumption. These include cashew nut (Anacardium occidentale), the marula (S. birrea), buchu (Agathosma betulina), the avocado (Persea americana), ilala palm (Hyphaene coriaceae), etc. (FAO, 1994). In addition, many trees provide forage for livestock; for example, buffalo thorn (Ziziphus mucronata subsp. Mucronata), shephered's tree (Boscia albitrunca), elephant bush (Portulacaria afra), sweet thorn (Acacia karroo), tagasaste (Chamaecytisus palmensis), mesquite (Prosopis spp.) and honey locust (Gleditsia triacanthos). In Karroo region, the sweet thorn ( $A$. karroo) is good source of fodder for sheep and cattle farming (Aucamo et al., 1984).

\section{Medicinal plants}

Medicinal plants are a special category of NTFPs which are highly prized in South Africa (Cunningham, 1988: 4 to 7). These plant materials are collected from trees, shrubs, climbers, bulbs, ephiphytes, leaves, roots, seeds, tubes, parasites. Some most popular species are the bastard onion wood (Cassipourea malosana), the Swazi ordeal tree (Erthrophleum lasianthum), the stinkwood (Octotea bullata), and pepper-bark tree (Warburgia salutaris) (FAO, 1994). They are used for self consumption and also traded for cash. Due to adherence to traditional healers and high costs of medicines, a large population in South Africa depends upon herbs. Some $80 \%$ of Africans use traditional medicines compared to $60 \%$ of the world's population in genera I (WHO, 2002).
There are approximately 200,000 practising traditional healers in South Africa (Kale, 1995). Rough estimates suggest that some 30 million out of 48 million people are treated by traditional healers. The Institute of Natural Resources (INR) at Pietermaritzburg, however, estimated that more than 7.5 million plant units are sold annually in 50 shops in KawaZulu-Natal alone. The plants units are also said to come from more than 600 species.

The trade in medicinal plants is concentrated in KwaZulu-Natal, Guateng, and Mpumalanga (Dold and Cocks, 2002) and low lying plains to the east of the Drakenberg escarpment (Botha et al., 2004). Major trading centres are Durban, Witswatersrand, and Mpumalanga (Botha et al., 2004). The trade has also taken toll on the sustainability of the medicinal plants trade. For example, one of the species is extinct, 39 species are endangered or vulnerable or declining, 24 species are classified as rare and vulnerable and 53 species are of intermediate status (FAO, 1999: 21).

\section{Other vegetal NTFPs}

South Africa's floral wealth has led to the development of indigenous cut flowers industry. The Rumohra adiantiformis, a fern, is used extensively in floral trade. Since 1981 the industry has grown rapidly to the value of US\$ 3 million per annum and employing about 300 people (Milton, 1987; Geldenhyus and van der Merwe, 1988). Epiphytic mosses from Mpumalanga (Transvaal) forests are also sold (Jacobsen, 1978). Indigenous flowers and bulbs contribute about 1 percent of the total national value of agricultural production in South Africa (FAO, 1994).

\section{Faunal NTFPs}

Hunting has been the part of existence of rural poor in South Africa. Generally domestic animals are reared for milk and draught purposes and wild animals are used as source of protein. Wild animals which are hunted for meat include various species of buck, genets, field mice, rock rabbits, porcupines, bush pigs and hares and monkeys at times (FAO, 1994). The by-products from hunted animals are hides, skin horns, bones which are sold for futher processing or final use. Horns and bones are used for making artefacts. Various animal parts are used as medicines such as scrub and cape hares, the porcupine and pole cat, pangolin (FAO, 1994).

Bush meat is also frequently consumed and this adds to the protein requirements of the communities involved in the hunting. The most hunted is the bush-pig (Cunningham et al., 1988: 8). Many more hunting and trapping of small animals is common, some of which is often sold for cash in the herb market in Durban. Fishing 
Table 2. Places of relative abundance of major NTFPs in South Africa

\begin{tabular}{|c|c|}
\hline NTFPs items & Places of relative abundance \\
\hline Fuel wood & Everywhere especially in and around commercial forests \\
\hline Baskets/mats (induma material) & Northern KwaZulu Natal, Empangeni and Port St. Johns area in Esatern Cape \\
\hline \multicolumn{2}{|l|}{ Brooms } \\
\hline Grass (ngonani) & In most parts of the country \\
\hline Palm leaflets (ilala) & Strictly along the coastal area especially around Empangeni \\
\hline \multicolumn{2}{|l|}{ Building materials } \\
\hline Laths (poles) & Everywhere especially in and around natural forests \\
\hline Grass (thatching) & Everywhere \\
\hline \multicolumn{2}{|l|}{ Wild foods } \\
\hline Wild fruits & $\begin{array}{l}\text { Around areas of thick natural forests (that is, Port St. Johns area, Nkandla } \\
\text { forest, Sand forests, Afromontane forests, coastal Lake zone and Dune forest, } \\
\text { the savannah etc) }\end{array}$ \\
\hline Spinach (imifino) & Old abandoned garden fields, Maputaland (Natal), Dune and Sand forests \\
\hline Bush meat/fish & $\begin{array}{l}\text { Mostly around game reserves and sanctuaries (i.e. Mkambati game reserve in } \\
\text { Eastern Cape, the savannah, Kosi estuary, northern KwaZulu Natal) }\end{array}$ \\
\hline Birds and Lepidoptera & Thick indigenous forests of Western cape, Eastern cape and KwaZulu Natal \\
\hline \multicolumn{2}{|l|}{ Medicinal plants } \\
\hline Inguduza (tube) & Mzimukhulu area, Natal mid-lands and far distant areas \\
\hline Ntongana (tubes) & Around Durban \\
\hline Mababaza (tubes) & All over Kwazulu Natal \\
\hline Maphipha (tubes) & All over KwaZulu Natal especially in wetter areas \\
\hline Ncishamililo (roots) & Around KwaZulu Natal \\
\hline Siphaha (bark) & Specifically from Transkei, Eastern Cape \\
\hline Twalitshe (bark) & From all over Durban \\
\hline Mkhondweni (bark) & KwaZulu Natal \\
\hline UMbinda (bark) & KwaZulu Natal \\
\hline Mluthu (bark) & KwaZulu Natal \\
\hline Ndiyaza (bark) & KwaZulu Natal, northern and mid-lands \\
\hline iTsango (seeds and leaves) & Everywhere mostly Lusikisiki around Nkozo area \\
\hline
\end{tabular}

Based on Gasana (1999).

is also frequent especially around Kosi estuary, northern Natal, (Cunningham et al., 1988: 8). One of the typical cash generating NTFPs items is birds and Lepidoptera (Cunningham et al., 1988: 8). The butterfly trade, common in the Southeast Asia, is steadily gaining attraction in South Africa.

Birds used for meat include the guinea fowl (Numida meleagris), the ostrich (Struthio camelus), francolin (Francolinus sephaena), the common quail (Coturnix coturnix) and various types of geese and ducks. Catching birds for rearing them as pet is a thriving business too. Commonly caught birds for pet are louries (Tauraco spp.), parrorts (poicephalus spp.) and the buntings (Emberiza spp.). Fishing is also an important activity for rural South Africans, particularly those near to the coast. A variety of reptiles are harvested for food such as lizards, leguaans, frogs and toads, turtles or tortoises, and snakes. Snake venom is being harvested for its therapeutic properties (FAO, 1994).

\section{COLLECTION AND MARKETING OF NTFPS}

The term collection of NTFPs is equivalent to harvesting 
Table 3. Selected indigenous species used for various cottage industries.

\begin{tabular}{|c|c|c|}
\hline Common name & Botanical name & Use \\
\hline 1. ilala palm & Hyphaene Coriacea & $\begin{array}{l}\text { Leaves are used for weaving } \\
\text { blankets and beer strainers }\end{array}$ \\
\hline $\begin{array}{l}\text { 2.Pod mahogany } \\
\text { Velvet bush wilow } \\
\text { Terminalia Sericea }\end{array}$ & $\begin{array}{l}\text { Atzelia quanzensis } \\
\text { Combretum molle }\end{array}$ & $\begin{array}{l}\text { Wood used for the making of grain } \\
\text { stamping mortars, bowls }\end{array}$ \\
\hline $\begin{array}{l}\text { Natal Mahogany } \\
\text { Torchwood } \\
\text { Tambati }\end{array}$ & $\begin{array}{l}\text { Trichilia emetica } \\
\text { Balanites maugani } \\
\text { Spirostachys African }\end{array}$ & $\begin{array}{l}\text { Wood used for making bowls, } \\
\text { spoons, and carved animals }\end{array}$ \\
\hline $\begin{array}{l}\text { Mat-rush } \\
\text { Monkey ranges }\end{array}$ & $\begin{array}{l}\text { Juncus Krausii } \\
\text { Strychnos madagascariensis S Spinasa }\end{array}$ & $\begin{array}{l}\text { Mat } \\
\text { Fruits are used for decorations }\end{array}$ \\
\hline $\begin{array}{l}\text { Bastard tambati } \\
\text { Cape plane } \\
\text { Natal plane }\end{array}$ & $\begin{array}{l}\text { Cleistanthus sweechteri } \\
\text { Ochna arboea } \\
\text { O. Natalia }\end{array}$ & Walking sticks \\
\hline $\begin{array}{l}\text { Hairy dtypetis } \\
\text { Coffee beans strychnos }\end{array}$ & $\begin{array}{l}\text { Drypetas } \\
\text { Strychnos henningsii }\end{array}$ & Gerranrdi \\
\hline Magu rope stems & Oncinotis inandensis & Basket frames and handles \\
\hline
\end{tabular}

Based on Gasana (1999) and FAO (1994).

of timber products from forest. The NTFPs involve parts of trees or plants which are collected for human use. Most women and children in rural South Africa collect NTFPs for meeting their consumption needs and or earning incomes. The climate plays an important role in determining the natural supply of NTFPs. For example, the wetter regions of the country, including the coastal belt along the Indian Ocean, produce a variety of NTFPs relative to that in the dryer interior regions. Collection activity depends upon a number of factors but to a great extent the opportunity cost of labour plays the significant role. Collection is more intensive in poor regions where poverty abounds; for example, a lot more collection of NTFPs takes place in the former homelands. The most collected NTFPs are medicinal plants, fuelwood, foods, flowers, craft and construction materials. The places of relative abundance of different NFFPs are given in Table 2.

A perusal of Table 2 reveals that fuelwood is collected in every part of the country, particularly in poor rural areas. The materials used for making baskets and mats are collected primarily in the areas of Port St. Johns and Empangeni--the north of Durban city. The materials for making brooms are collected almost every where in the country but the collection of palm leaflets (ilala) is restricted to coastal areas especially around Empangeni. The building materials are collected almost everywhere near thick natural forest areas. The collections of other foods such as spinach or mushrooms vary with season and are abundantly found in KwaZulu-Natal areas. Generally speaking, spinaches are in abundance in coastal areas during summer. Estimates suggest about $45 \%$ of household collectors chose to collect from coastal areas, whereas in winter about more than $80 \%$ of all household collectors travelled to long distances in the sand forest zone (Cunningham et al., 1988: 6).

The collection of medicinal plants and marketing seems to be the dominant activity. The varieties of medicinal plants listed in Table 3 are the most collected and most of them are sold in the herbal market in Durban city. The amount of collection depends on the family size, alternative income, season and the demand for the NTFP item. The annual collection is difficult to determine and this is one area where planners need to recognise the importance of NTFPs and their contribution to the rural economy, especially to the marginalised low-income group.

The collection season of most NTFPs depends on the item in question and the weather. Due to seasonal changes, the NTFPs of flora origin tend to die back in winter and flourish in summer (Table 4). For example, the collection of spinach goes on most of the year but its availability increases with the wet season from December to March. 
Table 4. Collection periods of some NTFPs in KwaZulu Natal.

\begin{tabular}{|c|c|c|c|c|c|}
\hline \multirow{2}{*}{ NTFP item } & \multirow{2}{*}{ Location } & \multirow{2}{*}{ Common areas } & \multicolumn{3}{|c|}{ Collection period } \\
\hline & & & Season & Peak period & End period \\
\hline Spinach & Sand forests & Lake zones & Oct. to May & Dec. to March & May \\
\hline Fuel wood & Everywhere & & - & May to Sept & - \\
\hline Building materials & Near natural forests & Former homelands & - & May to Sept. & - \\
\hline Grass(folder, thatching) & Most parts & Varied & Nov. to April & Dec. to March & April to May \\
\hline Flowers & Natural vegetation & Durban, coastal zone & Oct. to May & Dec. to Feb. & April \\
\hline $\begin{array}{l}\text { Craftwork (Baskets, } \\
\text { mats, sticks, etc) }\end{array}$ & Indigenous forest & $\begin{array}{l}\text { Port St. Johns, Sand } \\
\text { forests, Nkandla forests }\end{array}$ & Aug. to June & Dec. to March & - \\
\hline Medicinal plants & Everywhere & Natal mid-lands & - & Nov. to May & - \\
\hline
\end{tabular}

Based on Gasana (1999).

In winter season, collectors have to cover greater distances to Sand forests in search of the vegetables. Fuelwood is collected round the year, but its collection intensifies in winter when it is required for heat generation at the same time for cooking grains. For example, fuelwood collection in KwaZulu Natal is estimated to vary from 0.62 to 1.12 tonnes per capita per year and about $95 \%$ of domestic energy consumed by rural household is coming from fuelwood (Gandar, 1984: 7). This trend is envisaged to continue and fuelwood will remain the major source of domestic energy even with the current electrification programme of rural areas in the country. The building materials are generally collected throughout the year, but most house construction is done in winter and so the collection goes on during winter when there is less cultivation or agricultural work.

Estimates of economic value of all NTFPs in South Africa are difficult to find, some estimates can indicate their significance. For example, fuelwood value is estimated at R4.5 to R5.5 billion per annum (Damm and Triebel, 2008); the value of medicinal plants trade is assessed to be about US $\$ 415$ million per annum-about $5.6 \%$ of total health budget of the country (Campbell, 2007). Estimates on the value of handicrafts, building and household materials, and gathered foods are expected to be very high. Although it is pretty difficult to make an estimate of the total value of this sector in the economy, for certain it makes a significant part of the rural economy and possesses the potential for perking up the economic growth in the rural South Africa. It is hence an instrument for rural development in the country.

On the marketing side, the NTFPs (specifically the medicinal, brooms and craftwork) are distributed in local, regional, and national markets. The tradable NTFPs are collected from the rural areas and are marketed in the urban centres where the demand is steadily growing. The main buyers of the medicinal products are predominantly black communities while the craftwork and brooms are demanded by all. The craftwork items are marketed around tourist centers and their demand fluctuates seasonally, increasing during summer when foreign tourists visit Durban and other similar places during the peak periods (festival and summer times) in South Africa. This time coincides with the season when domestic tourists also flock to the coastal beaches of South Africa. The market for craftwork is distributed evenly and the main consumers are household, domestic and foreign tourists who frequently visit coastal areas/cities of the country. The craftwork materials are collected from remote areas of Eastern Cape and northern KwaZulu mainly around Port St. John area and Sand forests, respectively.

Most medicinal plants are sold in Durban herbs-bridge market--the centre of herb trade in Southern Africa. The wholesalers of medicinal parts come from far distances such as Mzimukulu, Empangeni, Transvaal, Swaziland and Mozambique or Lesotho. Most raw medicinal parts are processed in Durban and then re-sold.

\section{INCOME AND EMPLOYMENT GENERATION POTENTIAL}

NTFPs are a source of income and employment to many rural dwellers and to some in urban areas. This is particularly important because many rural dwellers do not have formal education and skills to get employment in formal organised sector. In this respect, the NTFPs via 
their collection, value addition and trade activities already reveal a great potential because the activities are performed manually and so absorb enormous labour force that would have otherwise remained perpetually unemployed.

Although there is a scarcity of data reflecting the contribution of NTFPs to the income and employment generation in South Africa, the trade chain made up of collectors, transporters, hawkers, wholesalers, retailers, mail-order companies, traditional healers, and exporters is large (Mander et al., 1996: 1). The trade was valued to be in the neighbourhood of US\$128 million per annum during 1990s and this contributed substantially to the poor in the generation of income and employment (Mander et al., 1996: 1). The new estimate suggests that it would be about US $\$ 415$ million (Campbell, 2007). The lack of formal statistical data on the NTFPs is basically attributed to the fact that most NTFPs are collected for meeting household subsistence requirements (a positive attribute) and the surplus is traded in the informal markets for cash income. One should also note that to some certain extent there exists the policy of neglect in recognising the importance of the NTFPs and their role in rural development. However, the value chain of NTFPs is labour intensive and there is a good scope for value addition through processing. One can therefore argue that income and employment generation can be increased via institutional support or through the development of existing collection and value addition activities.

When NTFPs are collected, they are further graded and processed, and in so doing value is practically added to them. The value addition activities take place in form of cleaning, shelling, heating, cooling, drying, fumigation, grading, bundling and storage. Market intermediaries, using their skills to assemble, mix and concoct the NTFPs, largely carry out this activity. The NTFPs tend to be bulky and their transportation in raw form has a negative effect on collectors. Ideally, in order to increase the net returns, it is necessary to process the NTFPs at collection points so as to reduce high transportation costs.

The major constraints in this respect are the limitedknowledge of and access to improved processing and packaging techniques, which provide high profits to the middlemen. For example, in one of the Indian states, it was found that Sal leaves gain ten times in value when stitched into plates and processed with polythene inserts. The same practice is evident and alive in Durban Bridge market dealing in medicinal plants. Bulbs, tubers, leaves, stems, barks and roots are collected up-country and sold to the urban traders who take the advantage of value addition skills and earn super-normal profit margins. The most common value addition activities in Durban market include, chopping, crunching, pounding, mixing, parking, bottling and wrapping techniques in case of medicinal products. It was found that value addition can raise price from 40 to $200 \%$ in Durban herb market (Gasana, 1999).

Evidences from various parts of the world suggest that NTFPs can be developed into a healthy and sustainable business. In African continent, the story of Marula ( $S$. birrea) is worth noting and it is now identified as "treasure tree" of Africa. In Limpopo province, Marula processing is done very intensively. Some 6000 collectors gather marula fruit for the production of Amarula liqueur and the tree is a vital source of income yielding $\$ 70$ per tree (http://www.new-org.infor/focusltem. php?a =1089). At the world level, in nearly all successful cases of enterprise development related to NTFPs, there was some institutional support in promoting the small-scale enterprises (SSEs). Similar support and attention is due in South Africa given the background that the majority of the population is still poor, rural based and rely directly on the extraction of NTFPs for survival.

\section{MANAGEMENT AND POLICY CHALLENGES}

From the preceding sections it has been established that NTFPs form an important resource in the lives of majority of South Africans in their subsistence survival as part of primary health care system, food nutrients, shelter needs, and income and employment generation avenues. Therefore, the role of NTFPs in the economy is to be taken seriously and they should be integrated in the mainstream economy. The research base on NTFPs and research network is not well developed.

Apparently, in South Africa, there is no forest policy or recognition whatsoever that includes the NTFPs and their positive contribution to the poor. This policy neglect is perhaps due to the fact that most NTFPs are in the informal and rural sector and are ignored by the development planners and policymakers of the country. There is, however, a need to recognise the efficacy of the informal sector in creation of jobs for the neediest people and thus revitalise rural development programs in the country. The reality on ground is that the poor people strive to earn income and employ themselves through increasing extraction of NTFPs and this inevitably reduces the stock of NTFPs_leading to unsustainable extraction of NTFPs.

Already, there is a general concern about the depletion of NTFPs in South Africa especially of medicinal origin due to unsustainable extraction rates. The concern is even higher with the people who directly depend on NTFPs for income and employment generation and more importantly for survival. It is important to note that, once the NTFPs are extinct, it is very difficult to reverse the consequences. Cunningham (1990: 985) reported that 15 medicinal plants were near to extinction in South Africa. Two important reasons (Cunningham, 1990: 985 to 986) for depletion and scarcity of these species were: (1) the 
problem of common property resource and unsustainable extraction rate; and, (2) most of the wetlands and coastal region that harboured most indigenous forest species were replaced by sugarcanes or exotic trees species under commercial plantations, thus squeezing the available land for collection of NTFPs. It is also to be noted that constant under-reporting of NTFPs from forests and woodlands have resulted into lesser importance being attached to them in the national accounting; consequently their role in supporting livelihoods and food security is also undermined (Dovie, 2003).

The White Paper on forestry in 1997 and subsequent National Forest Act of 1998 do recognize the NTFP resources indirectly but do not emphasize their role in terms economic significance for the rural poor and rural development. The White Paper categorically states that all South Africans have a stake in forestry but the people most involved are rural people and workers in the forestry sector (Department of Water Affairs and Forestry (DWAF), 1997: 7). Furthermore, women outnumber men in the rural areas as men go outside in search of employment; this means proper management of NTFPs will not only create rural development but also empower women and children against hunger and poor nutrition. For example, medicinal plants industry have played significant role in empowering large numbers of women and lack of it would render them destitute (Dold and Cocks, 2002: 596). In these circumstances, state intervention is to be crafted purposely bearing local realities to invigorate the local NTFP economy (Wynberg and Laird, 2007).

The rejuvenation and proper development of the NTFPs sector requires a set of good policies that will auger well for the growth and development of entrepreneurial activity in this sector without depleting the stock of NTFP resources. It is obvious that promotion of small scale enterprises (SSEs) based on NTFPs would meet the objective of more equitable distribution of profits and also promote sustainable extraction. The rural development initiative hence enjoins the responsibility on to the government to develop a policy framework or strategy to harness this resource on a sustainable basis. For this purpose, a five-pronged policy strategy is suggested (Figure 1):

1. Transfer of management and organization skills to the collectors of NTFPs;

2. Promotion of value addition activities at the local and regional economies;

3. Improvement in marketing channels so as to pass benefits on to collectors of NTFPs;

4. Exploring the regional and national markets; and

5. Strengthening the local institutions.

The first and foremost thing for regenerating the SSEs is the development of skills among the rural people. Many collectors who pursue the small-sale enterprises do not have the skills required for running a business; these include skills of organization, marketing, and bookkeeping. This is because many of these collectors are not literate and not exposed to the outside world. It is hence essential to transfer basic literacy and management skills to people in the villages for managing the change. The management skills require the villagers to develop skills of organization, book-keeping, mar-keting, and skills of cognizing the market patterns and development.

The second most important task is to promote the value addition activities in local village or regional economy, thus saving the exportation of jobs and income to faraway areas. This also gives a higher net price to local collectors. The value can be increased by sorting produce by quality grades or by performing simple value adding operations such as separation of dirt, pulverizing, powdering, and making tablets and so on. For example, the Gujarat State Forest Development Corporation (GSDFDC) in India enforced the standardization and grading of NTFPs and thus passed on large benefits to tribal collectors. Similarly, the GSFDC undertook various simple processing operations on NTFPs of medicinal value and at times this resulted into as high as $4000 \%$ increase in the value of raw NTFP through simple technology. Another good example is the efforts of Kalahan Educational Foundation (KEF) in Philippines. In 1980, the KEF members started a food processing center and began making jam and jellies from forest fruits, with an intention to capture $10 \%$ of the high-end market in Manilla. By 1995, the center was providing cash incomes to some 150 local families (Rice, 1995). Several such success stories exist and teach us that local processing is the key to the sustainable management of NTFPs.

The third important change is to revamp the marketing system. Currently, there exist many middlemen in marketing chain from collectors to final consumer. This finally reduces the net price to the NTFP collectors as marketing margins constitute a big proportion of consumer's price. The higher marketing margins can be associated with high risk involved but they can be exploitative if middlemen use their bargaining power to their advantage. In these circumstances, the co-operative or community-based enterprises have worked better. Less attention to local markets of NTFPs can diminish their role in supporting livelihood and potentially lead to marginalization of rural poor (Shackleton et al., 2007).

The fourth most important policy variable is to explore the regional and national markets. International demand alone is likely to yield short-term benefits unless the product in question is well-established. Search for regional and national markets can be more rewarding, for it is cost-efficient and hassle-free. Regional markets can thus serve as key to the NTFP trade (FAO, 1995). For example, Amla (Emblica officinalis), a fruit tree which 


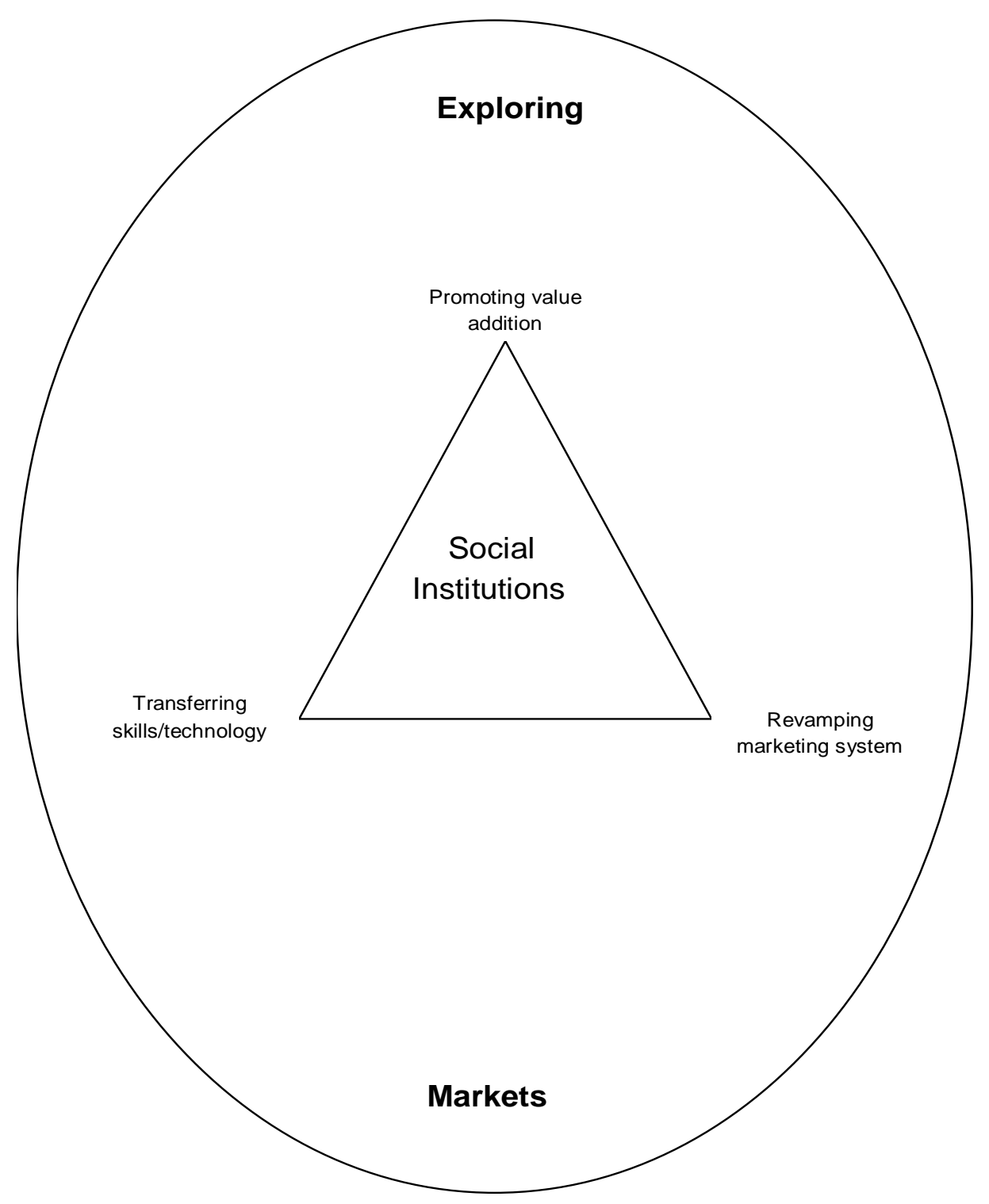

Figure 1. A five-pronged strategy to revitalize the NTFP-Economy of South Africa.

grows in the forests of Gujarat, India, is an important NTFP; tribal collectors sold its raw fruits at a very low price as they could not store it long. But, once they learn to dry it fruits, the prices climbed up. Thus, simple processing allowed them to store it long and also to sell their produce throughout the province of Gujarat. In Thailand, the extraction and processing of Catechu (Acacia catechu) flourished well when they found a regional and export market in India (Wanida et al., 1993). Many NTFPs in Southern Africa have a good regional and international market and can fetch good return to collectors. However, lack of coordinated efforts on the part of these people disenables them to enjoy higher returns. A co-operative marketing framework can hence effectuate these gains to collectors.

The fifth most important policy variable is to provide a set of local institutions which can help the change to take place in the rural setting. For example, increased demand pressure for consumption of NTFPs has led entrepreneurs to harvest fuelwood from communal areas without approval of institutions or residents (Twine, 2002). The decreased regulatory power of traditional authorities and lack of replacement with viable structure of local government or other agencies has helped the unsustainable extraction of NTFPs (Williams and Shackelton, 2002). The strong local institutions and supportive national policies are a must for making smallscale enterprises driven by communities a success. 
Strong community based traditions are a plus factor which augur the success of local businesses. These can be in terms of some collective and co-operative ventures.

\section{CONLUSIONS AND POLICY GUIDELINES}

South African forests provide a variety of NTFPs ranging from building materials to food and medicinal products. Economically, the NTFPs sustain the rural and peri-urban poor in meeting their subsistence needs; any shortage of them would exacerbate their poverty levels. The most direct beneficiaries of NTFPs are the landless and lowincome group with little or no formal education. This limits their chances to secure any job in the formal sector. The majority of rural dwellers of South Africa fall within this category. The most frequently utilised NTFPs include fuelwood, medicinal plants and animals, household materials, gathered foods, building materials and handicraft. The NTFPs generate higher potential for income and employment because the collection, value addition and their trade activities are labour intensive in nature and their labour absorption capacity is enormous. These products sustain people during difficult periods and provide supplementary income during other periods.

It is however important to mention that one of the major problems afflicting the NTFPs sector is the conscious policy neglect. Unlike timber forest products, which benefit from a host of policy, strategy and legislative support mechanisms, the NTFPs are grossly neglected and given no attention. Consequently, the role of NTFPs in the rural economy in particular is not appropriately addressed in developmental planning, programs and projects. This ought not to be the case given that people are critically dependent on NTFPs (including fuelwood and fodder) for subsistence and cash needs. Also, NTFPs in South Africa have not been screened to identify those with the most potential for mainstream development. South Africa has about $35 \%$ of people who live below poverty line in rural areas and suffer from hunger and malnutrition; the development of NTFP economy can contribute a lot towards poverty alleviation and reducing hunger. However, lack of appropriate policy strategies circumvent this change at present time. The state is hence supposed to take this pioneering role of stimulating this underperforming economy of NTFPs. An intensive profiling of this industry is hence the need of the hour prior to engaging in the policy formation process.

A five pronged policy strategy is suggested to invigorate the NTFP-economy by promoting the small-scale enterprises based on NTFPs and by managing them on a sustainable basis. These five policy variables are: (1) transfer of management and organization skills to the collectors of NTFPs; (2) promotion of value addition activities at the local and regional level; (3) improvement in marketing channels so as to pass benefits on to collectors of NTFPs; (4) exploring regional and national markets, (5) strengthening the local institutions. The government has a clear role of providing this coordination and initial financing to support this development change needed direly and the study proposes that an integrated development plan be phased in by the respective ministry.

\section{REFERENCES}

Adler E (1934). Nutritive Value of Locusts. Farming South Afr. 6:29.

Aucamo AJ, Danckwerts JE, Venter JJ (1984). The production of potential of an Acacia karroo community utilized by cattle and goats. J. Grassland Soc. Southern Afr. 1(1):29-32.

Botha JET, Witkowski F, Shackleton CM (2004). Market Profiles and Trade in Medicinal Plants in Lowveld, South Africa. Environ. Conserv. 31(1):38-46.

Bower B (2001). Human ancestors had taste for termites-hominid research. Science News.

Booth FEM, Wickens GE (1988). Non-Timber Uses of Selected Arid Zone Trees and Shrubs in Africa. FAO Conservation Guide Rome p.19.

Campbell C (2007). Traditional medicine supplies falling as demand rises. Science and Development Network. Available at: http:www.scidev.net/en/policy-breifs/

Central Intelligence Agency, CIA (2009). The world fact book. Available at: http://www.cia.gov/library/publications/the-world-factbook.

Crafford JE (1991). Insects as Source of Food, Folklore and Folk Taxonomy in Venda. Proceedings of the 8th Entomological Congress, Bloemfontein.

Chanyenga TF (1998-2000). Non-wood forest products in Malawi, ECFAO Partnership programme. Lilongwe.

Cunningham $A B$ (1987). Commercial craftwork: balancing out human needs and resources. South Afr. J. Bot. 53(4):259-266.

Cunningham AB (1988). An Investigation of the Herbal Medicinal Trade in KwaZulu-Natal. Instit. Nat. Resour. Investig. p.29.

Cunningham AB, Cooper KH, Cawe SG (1988). The value of indigenous forest to the people of South Africa. McKenzie B. Ed; Guidelines for the Sustained Use of Indigenous Forests and Forest Products. Pretoria: CSIR. (FRD Ecosystems Programme Occasional Report 35).

Cunningham AB (1990). People and Medicines: The Exploitation and Conservation of Traditional Zulu Medicine Plants. Instit. Nat. Resour. p. 67.

Damm O, Tribel R (2008). A Synthesis Report on Biomass Energy Consumption and Availability in South Africa. A report prepared for ProBEC, GTZ.

Department of Water Affairs and Forestry, DWAF (1997). The White Paper in National Water Policy for South Africa. Pretoria: Government of South Africa.

Dold AP, Cocks ML (2002). The trade in medicinal plants in the Eastern Cape province, South Africa. South Afr. J. Sci. 98:589-597.

Dovie DB (2003). Using secondary forest resources as indicators for developing forestry partnerships, A paper presented in the $12^{\text {th }}$ World Forestry Congress. Nov.21-28, 2001. Available at: http://www.fao.org.DOCREP/ARTICLE?WFC/XII/0226-A1.HTM

Dyson A (1998). Discovering Indigenous Healing Plants of the Herb and Fragrance Gardens at Kirstenbosch National Botanical Garden. Cape Town: The Printing Press.

Food and Agriculture Organization (FAO) (1994). NWFP: A Regional Expert Consultation for English-Speaking African countries. Rome: FAO. Available at: http://www.fao.org/documents/pub_dett.asp/ .

Food and Agriculture Organization, FAO (1999). Toward a harmonized definition of non-wood of forest products. Unasylva p.198.

Gandar MV (1984). Wood as a source of fuel in South Africa. South Afr. For. J. 129(1):1-9.

Gasana C (1999). A profile and an analysis of south African commercial 
forestry industry with special emphasis on exploring non-timber forest products (NTFPs), Unpublished Masters Thesis, University of Natal, Durban.

Geldenhyus CJ, Van der Merwe CJ (1988). Population structure and growth of the fern Rumohra adiantiformis in relation to fern harvesting in the Southern Cape forests. South Afr. J. Bot. 54:352-362.

Grivetti LE (1979). Kalahari agro-pastoral hunter-gathers: the Tswana example. Ecol. Food Nutr. 7:235-256.

Griffin NJ, Banks DI, Mavrandonis J, Shackleton CM, Shackleton SE (1992). Household Energy and Wood Use in a Peripheral Rural Area in The Eastern Transvaal Lowveld. Pretoria: Dept. Mineral Energy Affairs p.217.

Jacobsen NHG (1978). An investigation into the ecology and productivity of epiphytic mosses. J. South Afr. Bot. 44:297-312.

Junod HA (1913). The Life of a South African Tribe. Volume II. London: Macmillan.

Kale R (1995). Traditional healers in South Africa: a parallel health care system. Br. Med. J. 310:1182-1185.

Kusters K, Achdiawan R, Belcher B, Perez MR (2006). Balancing development and conservation: an assessment of livelihood and environmental outcomes of non-timber forest products trade in Asia, Africa, and Latin America, Ecology and Society, 11(2):20-22. (Online Available at: http://www.ecologyandsociety.org/vol11/iss2/art20/).

Makhado RA, von Maltitz GP, Potgieter MJ, Wessels DCJ (2009). Contributions of woodland products to rural livelihoods in the northeast of Limpopo province, South Africa. South Afr. Geogr. J. 91(1):46-53.

Mander M, Mander J, Breen C (1996). Promoting the Cultivation of Indigenous Plants for Markets: Experience from KwaZulu Natal. Instit. Nat. Resour. Occasional p.167.

Mander M (1998). The Marketing of Indigenous Medicinal Plants in South Africa: A Case Study in KwaZulu-Natal. FAO and Durban City. Available at: http://www.fao.org/docrep/W9195E/W915E00.htm.

Milton SJ (1987). Growth of seven-weeks fern (Rumohra adiantiformis) in the Southern Cape forests: implications for management. South Afr. For. J. 143:1-4

Mutenje MJ, Ortmann GF, Ferrer SDR (2011). Extraction of nontimberforest products as a coping strategy for HIV/AIDS-afflicted rural households in south-eastern Zimbabwe. Afr. J. AIDS Res. 10(3):195206.

Padoch C (1988). Aguaje (Mauritia flexuosa (I.f) in the economy of liquitos, Peru. Adv. Econ. Bot. 6:219-234.

Paumgarten F, Shackleton C (2011). Gender, non-timber forest products, household surveys, poverty alleviation, livelihoods, rural economy. Popul. Environ. 33(1):108-131.

Preston-Whyte E (1983). Black Women in the Craft and Curio Trade in Kwazulu and Natal. Pretoria: HSRC Report.
Rice D (1995). Forest niches: sustainable livelihood for upland dwellers with emphasis on food processing. In: PB Durst and Bishop A, Eds. Beyond Timber: Social, Economic and Cultural Dimensions of NonWood Forest Products in Asia and the Pacific. Bangkok, Thailand. FAO Regional Office for the Asia and the Pacific.

Shackleton SE, Shackleton CM, Cousins B (2000). The economic value of land and natural resources to rural livelihoods: case studies from South Africa. In: Cousins B. Ed. At the Crossroads: Land and Agrarian Reform in South Africa in to the $21^{\text {st }}$ Century. School of Government, University of Western Cape pp.35-67.

Shackelton CM, Shackleton SE (2004). The importance of non-timber forest products in rural livelihood security and as safety-nets: evidence from South Africa. South Afr. J. Sci. 100:658-664.

Shackleton S, Shanley P, Ndoye O (2007). Invisible but viable: recognizing local markets for ntfps. Int. For. Rev. 9(3):697-712.

Teffo LS (2006). Nutritional and Medicinal Value of the Edible Stingbug: Encosternum delegorguei Spinola consumed in the Limpopo Province of South Africa and Its Host Plant Dodonaea viscose jcq. var. angustifolia. Department of Paraclinical Science. University of Pretoria.

Twine W (2002). The fuelwood problem: are we reaching a crisis point? Environ. Today 2:20-21.

United Nations Development Programme (UNDP) (2005). Millennium Development Report-South Africa. Available at: http://www.undp.org.za/millennium-development-goals.

Vedeld P, Angellsen A, Sjaastad E, Berg GK (2004). Counting on the Environment: Forest Incomes and the Rural Poor. Washington DC: World Bank.

Wanida S, Denrungruang P, Nilkamhaeng N, Sroithongkham P (1993). Utilization of Acacia catcheu wild in Thailand: improving a cottage industry. In: Awang K, Taylor DA Eds; Acacias for Rural, Industrial, and Environmental Development. Bangkok, Thailand. Winrock International and FAO Regional Office for Asia and the Pacific.

Williams AT, Shackleton C (2002). Fuelwood Use in South Africa: Where in the $21^{\text {st }}$ Century?. Southern Afr. For. J. 196:1-7.

White C, Bank L, Jones S, Mehlwana M (1997). Restricted electricity use among poor urban households. Dev. Southern Afr.14:413-430.

World Health Organization, WHO (2002). WHO Traditional Medicine Strategy 2002-2005. Geneva: WHO.

Wynberg RP, Laird SA (2007). Less is often more: governance of a nontimber forest product, marula (sclerocarya virrea subsp. caffra) in Southern Africa" Int. For. Rev. 9(1):475-490. 